\title{
Activated biomass of the green microalga Chlamydomonas variabilis as an efficient biosorbent to remove methylene blue dye from aqueous solutions
}

\author{
Reda M Moghazy* \\ Water Pollution Research Department, National Research Centre, El Buhouth Str, Dokki, Cairo, 12622, Egypt
}

\begin{abstract}
The raw and activated biomass of a green microalga, Chlamydomonas variabilis, were investigated as adsorbents for the removal of methylene blue (MB) dye from aqueous solutions. Chlamydomonas variabilis was isolated and cultivated to obtain a sufficient algal biomass. The collected biomass was first oven-dried and then activated by $\mathrm{H}_{2} \mathrm{SO}_{4}$. The results obtained showed that the optimum adsorption of $\mathrm{MB}$ occurred over $30 \mathrm{~min}$ of contact time at $\mathrm{pH} 7$ and an biosorbent dose of 1.5 and $1.0 \mathrm{~g} \cdot \mathrm{L}^{-1}$ of dried biomass and activated biosorbent, respectively. Point of zero charge (pHpzc) was recorded at $\mathrm{pH} 6.8$ and 6.9 for dried and activated biomass, respectively. The activated biomass was a more effective biosorbent than was the dried biomass: At a MB concentration of $82.4 \mathrm{mg} \cdot \mathrm{L}^{-1}$, the minimum removal was greater than $98 \%$ using $1 \mathrm{~g} \cdot \mathrm{L}^{-1}$ activated biomass with a maximum adsorption capacity $\left(q_{\max }\right)$ of $115 \mathrm{mg} \cdot \mathrm{g}^{-1}$, whereas at a MB concentration of $56.4 \mathrm{mg} \cdot \mathrm{L}^{-1}$, the maximum removal did not exceed $80.8 \%$ using $1.5 \mathrm{~g} \cdot \mathrm{L}^{-1}$ raw biomass with a $q_{\max }$ of $18.3 \mathrm{mg} \cdot \mathrm{g}^{-1}$. Furthermore, the Freundlich and Langmuir isotherm models of adsorption showed a better model fit when using activated biomass than when using raw biomass, with the former yielding $R^{2}$ values greater than 0.9. The kinetic data suggest that the adsorption of $\mathrm{MB}$ follows the pseudo-second-order equation better than the pseudo-first-order one. This study demonstrates that the activated biomass of Chlamydomonas variabilis can be used as an effective biosorbent for the treatment of dye-containing wastewater streams.
\end{abstract}

Keywords: Chlamydomonas variabilis, activated biomass, biosorption, methylene blue dye treatment

\section{INTRODUCTION}

The environmental impacts caused by agricultural and industrial effluents, and release of urban solid waste into surface water and open dumpsters, have worsened in recent years, drawing the concern of all segments of society (Monteiro et al., 2017; Pinto et al., 2016; Bharathi and Ramesh, 2013). Over 10000 different types of dyes and pigments are used in the textile and printing industries. The industrial use of synthetic dyes involves complex compounds such as triphenyl methane, azo-dyes, and heterocyclic/polymeric structures. Elimination of these hazardous pollutants and their dangerous effects is of concern for the environment and society (Zazouli and Moradi, 2015).

Methylene blue (MB) is an important basic dye that is widely used for dyeing fabric, calico, cotton and tannin printing, as an oxidation-reduction indicator, purified zincfree form, as an antiseptic and for other medicinal purposes. Although not particularly hazardous, methylene blue can have various harmful effects (Hamdaoui and Chiha, 2007). The dye can cause permanent or temporary eye burns in humans and other animals. If the dye is swallowed, it can result in various symptoms, including gastrointestinal tract irritation, nausea, vomiting, and diarrhoea. If inhaled, it can cause methemoglobinemia, cyanosis, convulsions, tachycardia, and dyspnea. Methylene blue can also irritate the skin (Senthilkumaar et al., 2005; Ghosh and Bhattacharyya, 2002). Due to these effects, it is important to remove methylene blue from wastewaters. Conventional methods of methylene blue removal, such as chemical oxidation and adsorption, chemical precipitation and chemical coagulation,

\footnotetext{
To whom all correspondence should be addressed.

e-mail:rm.mogazy@nrc.sci.eg; remog81@gmail.com

Received 20 January 2018, accepted in revised form 27 November 2018.
}

have limitations to their use, because they are cost-intensive and produce large amounts of solid waste, creating a higher pollution potential than that of the effluents treated (Al-Fawwaz and Abdullah, 2016).

Over the past few decades, the biosorption of dyes by microorganisms has been developed as a cost-effective and ecofriendly technique. The term 'biosorption' can be defined as the passive absorption of organic and inorganic species such as dye molecules and metal ions, by the microbial biomass (Banat et al., 1996). Many types of microbial biomasses such as bacterial (Kalme et al., 2010), microalgal (Wang et al., 2007; Badr et al., 2016; Clark and Anliker, 1980), and fungal bomass (Fu and Viraraghavan, 2002), can act as an efficient biosorbent for toxic dye removal from industrial effluents.

Among the various microbes, microalgae have been demonstrated as a superior candidate for the removal of dye molecules due to their abundant occurrence in all habitats, their high surface area, and low cost and availability (Liang et al., 2017). Many functional groups on the algal cell wall, such as hydroxyl, amide, carboxyl, and sulphurhydryl, etc., are responsible for absorption of dye molecules (Sarwa and Verma, 2013). Previous studies have indicated that the green algae Enteromorpha spp. and Spirogyra rhizopus have high adsorption capacities for MB and acid red 274, respectively. Non-living biomass appears to have greater adorption potential than does living biomass because it requires no nutrient supply and is not affected by toxicity in wastewater treatment (Liang et al., 2017).

A widely used, but expensive, technology for dye adsorption is activated carbon adsorption. Therefore, there is a growing interest in the modification of low-cost, readily available natural materials for biosorption of metal ions and dyes. Lowcost adsorbents include adsorbents that are abundant in nature, waste materials from other industries, or by-products. Recently, extensive efforts have been made to develop new adsorbents and improve existing ones, such as granular activated carbon, 
iron oxide coated sand, and porous cellulose carrier modified with polyethyleneimine. (Badr et al., 2016).

The main objective of this work was to evaluate the removal effectiveness of $\mathrm{MB}$ removal by raw and activated biomass of the green microalga Chlamydomonas variabilis.

\section{MATERIALS AND METHODS}

\section{Preparation of biosorbents}

Algae were collected from the Nile River at the intake of El-Giza Water Works by using a phytoplankton net $(80 \mu \mathrm{m}$ mesh). To remove dirt and/or other impurities present in the raw materials, the collected algal biomass was washed several times with deionized water. Algal species were then isolated using $B_{11}$ medium (Stanier et al., 1971).

\section{Isolation, purification and identification of algal strain}

The algal strain was isolated by spreading $0.1 \mathrm{~mL}$ water samples into Petri dishes containing modified $\mathrm{BG}_{11}$ medium plus $1.5 \%$ agar (for solidification). Single colonies of algae were then re-cultivated in specified liquid media as nonaxenic batch cultures $(50 \mathrm{~mL})$. Re-cultivation was performed at $25 \pm 2^{\circ} \mathrm{C}$ under a photoperiod of $24 \mathrm{~h}$ with white fluorescent lamps at light intensity $\approx 2500 \mathrm{~lx}$. The green alga (Chlamydomonas variabilis) were isolated and purified in nitrate with modification of $0.3 \mathrm{~g} \cdot \mathrm{L}^{-1} \mathrm{NaNO}_{3}$ (see Table 1). Algal identification was performed using the identification keys (Komárek and Fott, 1983; Friedrich, 1976; Geitler, 1932).

\section{Cultivation of isolated algal strains}

The algal isolate of Chlamydomonas variabilis was cultivated in $B_{11}$ medium (see Table 1) to obtain a sufficient amount of algal biomass for the batch adsorption experiments. Mass multiplication and incubation was carried out under white fluorescent lamps at a light intensity of $\approx 2500 \mathrm{~lx}$ and a temperature of $25 \pm 1^{\circ} \mathrm{C}$ for 7 days. Biomass was then harvested by centrifugation ( $2000 \mathrm{r} \cdot \mathrm{min}^{-1}$ for $15 \mathrm{~min}$ ) into $100 \mathrm{~mL}$ sterile (polypropylene) centrifuge tubes, washed with generous amounts of deionized water, resuspended and washed again.

\section{Drying of algal biomass}

The algal biomasses were oven-dried at $70^{\circ} \mathrm{C}$ for $24 \mathrm{~h}$ to constant weight and then ground by using an agate stone mortar and pestle to obtain a powdered homogeneous dried algal biomass.

\section{Activation of dried algal biomass}

Five hundred milligrams of dried biomass was gradually added to $400 \mathrm{~mL}$ of $98 \% \mathrm{H}_{2} \mathrm{SO}_{4}$. The resulting mixture was maintained at room temperature for $24 \mathrm{~h}$ and then subjected to refluxing in a fume hood for $5 \mathrm{~h}$. After cooling, the reaction mixture was poured into ice water $(2 \mathrm{~L})$ and filtered. The filtrate was repeatedly washed with distilled water and soaked in $1 \%$ $\mathrm{NaHCO}_{3}$ solution to remove any remaining acid. The sample was then washed with distilled water until the $\mathrm{pH}$ of the activated carbon reached 6 , The sample was then oven-dried at $160^{\circ} \mathrm{C}$ for $48 \mathrm{~h}$ and then stored in a glass bottle until used (El-Sikaily et al., 2007).

\begin{tabular}{|c|c|}
\hline \multicolumn{2}{|c|}{$\begin{array}{c}\text { TABLE } 1 \\
\text { BG }_{11} \text { medium composition } \\
\end{array}$} \\
\hline Macroelement nutrient & Concentration $\left(\mathrm{mg} \cdot \mathrm{L}^{-1}\right)$ \\
\hline $\mathrm{NaNO}_{3}$ & 1500.00 \\
\hline $\mathrm{K}_{2} \mathrm{HPO}_{4}$ & 40.00 \\
\hline $\mathrm{MgSO}_{4} \cdot 7 \mathrm{H}_{2} \mathrm{O}$ & 75.00 \\
\hline $\mathrm{CaCl}_{2} \cdot 7 \mathrm{H}_{2} \mathrm{O}$ & 36.00 \\
\hline Citric acid & 6.00 \\
\hline $\mathrm{Na}_{2} \mathrm{CO}_{2}$ & 20.00 \\
\hline $\mathrm{Na}_{2}$ EDTA & 1.00 \\
\hline Ferric ammonium citrate & 6.00 \\
\hline Microelement nutrient & Concentration $\left(\mathrm{g} \cdot \mathrm{L}^{-1}\right)$ \\
\hline $\mathrm{H}_{3} \mathrm{BO}_{3}$ & 2.860 \\
\hline $\mathrm{MnCl}_{2} \cdot 4 \mathrm{H}_{2} \mathrm{O}$ & 1.810 \\
\hline $\mathrm{ZnSO}_{4} \cdot 7 \mathrm{H}_{2} \mathrm{O}$ & 0.222 \\
\hline $\mathrm{Na}_{2} \mathrm{MoO}_{4} \cdot 2 \mathrm{H}_{2} \mathrm{O}$ & 0.390 \\
\hline $\mathrm{CuSO}_{4} \cdot 5 \mathrm{H}_{2} \mathrm{O}$ & 0.079 \\
\hline $\mathrm{Co}\left(\mathrm{NO}_{3}\right)_{2} \cdot 6 \mathrm{H}_{2} \mathrm{O}$ & 0.0494 \\
\hline
\end{tabular}

\section{Biosorbent characterization}

\section{FT-IR analysis of dried and activated algae}

Fourier transform infrared spectroscopy (FT-IR) analysis of the raw and activated biosorbents was performed in the range of the infrared spectra within 400 to $4000 \mathrm{~cm}^{-1}$, and spectrum analysis was performed according to Guibaud et al. (2003.

\section{High-resolution transmission electron microscope (HRTEM)}

Algal biomass specimens were examined under a high-resolution transmission electron microscope (JEM-2100 JEOL) according to Williams and Carter (1996. HRTEM allows evaluation of the morphological characteristics of the algal biomass surface and measurement of the pore fractions and particle sizes to determine if they will be at the nanoscale size $(1-100 \mathrm{~nm})$ or not.

\section{Energy dispersive X-ray microanalysis (EDX)}

Energy dispersive X-ray microanalysis techniques can be used to determine the distributions of various elements inside the biomass (Figueira et al., 1999).

\section{Preparation of adsorbate}

Different concentrations of MB (with the molecular formula $\mathrm{C}_{16} \mathrm{H}_{18} \mathrm{ClN}_{3} \mathrm{~S} \cdot \mathrm{X} \mathrm{H}_{2} \mathrm{O}$ ), with a chemical structure as shown in Fig. 1 were prepared by dilution of a $1000 \mathrm{mg} \cdot \mathrm{L}^{-1}$ stock solution.

\section{Batch adsorption experiments}

The effects of $\mathrm{pH}$ (3-9), biosorbent dosage $\left(0.125-3 \mathrm{~g} \cdot \mathrm{L}^{-1}\right)$, contact time (0-60 $\mathrm{min})$, and initial dye concentration (20-80 mg. $\left.\mathrm{L}^{-1}\right)$ on $\mathrm{MB}$ removal were investigated. Biosorbents were placed in $250 \mathrm{~mL}$ stoppered reagent bottles at a constant shaking speed $\left(150 \mathrm{r} \cdot \mathrm{min}^{-1}\right)$. All of the experiments were carried out at room temperature $\left(25^{\circ} \mathrm{C} \pm 2^{\circ} \mathrm{C}\right)$. The samples 
<smiles>CN(C)c1ccc2nc3ccc(=[N+](C)C)cc-3sc2c1</smiles>

Figure 1

Chemical structural formula of $M B$

were centrifuged and $\mathrm{MB}$ concentration in the supernatant was determined at $665 \mathrm{~nm}$ using a UV-visible spectrophotometer (Cary 100 UV-Vis).

\section{Determination of point of zero charge $\left(\mathrm{pH}_{\mathrm{pzc}}\right)$}

$\mathrm{pH}_{\mathrm{pzc}}$ is a significant variable to indicate the biosorption ability on the surface of the biosorbent; it is performed by adopting the method of Brouers and Al-Musawi (2015). The dried and activated biosorbent of $0.2 \mathrm{~g}$ was added to $250 \mathrm{~mL}$ stoppered reagent bottles with different $\mathrm{pH}$ values at a constant shaking speed $\left(150 \mathrm{r} \cdot \mathrm{min}^{-1}\right)$ for $30 \mathrm{~min}$. The final $\mathrm{pH}\left(\mathrm{pH}_{\mathrm{f}}\right)$ was measured and the graph of $\Delta \mathrm{pH}\left(\Delta \mathrm{pH}=\mathrm{pH}_{0}-\mathrm{pH}_{\mathrm{f}}\right)$ against the initial $\mathrm{pH}\left(\mathrm{pH}_{0}\right)$ was plotted. The $\mathrm{pH}_{\mathrm{PZC}}$ is finally derived from the curve when $\Delta \mathrm{pH}=0$.

\section{Adsorption isotherms}

The relationship between $\mathrm{MB}$ biosorption capacity and $\mathrm{MB}$ concentration at equilibrium has been described by two sorption isotherm models: the Langmuir (Langmuir, 1918) and Freundlich models (Freundlich, 1907). The two biosorption isotherms were applied to both a raw biosorbent and activated biosorbent to determine the surface properties and affinity of the biosorbents and to compare their biosorptive capacities for MB. These isotherms are represented by the following linearized equations:

\section{Langmuir isotherm}

$$
C_{e} / q_{e}=1 / b q_{\max }+C_{e} / q_{\max }
$$

where $q_{\mathrm{e}}$ is the amount of dye sorbed per unit mass onto dried algae $\left(\mathrm{mg}^{-1} \mathrm{~g}^{-1}\right), q_{\max }$ is maximum adsorption capacity at complete monolayer coverage $\left(\mathrm{mg} \cdot \mathrm{g}^{-1}\right)$, and $b$ is a Langmuir constant that relates to the heat of adsorption $\left(\mathrm{mg} \cdot \mathrm{L}^{-1}\right)$.

\section{Freundlich isotherm}

$$
\log q_{e}=\log k_{f}+1 / n \log C_{e}
$$

where $q_{\mathrm{e}}$ is the equilibrium adsorption capacity $\left(\mathrm{mg}^{-1}\right), C_{\mathrm{e}}$ is the equilibrium concentration of dye in the solution $\left(\mathrm{mg} \cdot \mathrm{L}^{-1}\right)$, $k_{\mathrm{F}}$ represents the adsorption capacity when the dye equilibrium concentration equals to 1 (mg. $\mathrm{g}^{-1}$ ), and $n$ is the degree of dependence of adsorption on the equilibrium concentration.

\section{Application of kinetic modeling}

In order to examine the controlling mechanism of the adsorption processes, such as mass transfer or chemical reaction, two kinetic models, including the pseudo-first-order equation (HO et al., 2000), and pseudo-second-order equation (Weber and Morris 1963) were applied, as expressed by the following two equations:

\section{Pseudo-first-order equation}

$$
\log \left(q_{e}-q_{t}\right)=\log q_{e}-\frac{K_{1} t}{2.303}
$$

where $k_{1}\left(1 \cdot \mathrm{min}^{-1}\right)$ is the rate constant of a pseudo-first-order equation, and $q_{\mathrm{e}}\left(\mathrm{mg} \cdot \mathrm{g}^{-1}\right)$ and $q_{\mathrm{t}}\left(\mathrm{mg} \cdot \mathrm{g}^{-1}\right)$ are the amount sorbed at equilibrium and at time $t$ (min), respectively. A straight line of $\ln \left(q_{\mathrm{e}}-q_{\mathrm{t}}\right)$ versus $t$ suggests that this kinetic model is applicable to the data.

\section{Pseudo-second-order equation}

$$
\frac{t}{q_{t}}=\frac{t}{K_{2} q_{e}^{2}}+\frac{t}{q_{e}}
$$

where $k_{2}\left(\mathrm{~g} \cdot \mathrm{mg}^{-1} \cdot \mathrm{min}^{-1}\right)$ is the rate constant of a pseudosecond-order equation and $q_{\mathrm{e}}\left(\mathrm{mg} \cdot \mathrm{g}^{-1}\right)$ is the amount sorbed at equilibrium.

\section{RESULTS AND DISCUSSION}

\section{Characterization of algal biosorbents}

\section{FT-IR spectroscopy}

Several functional groups were found in the structure of raw and activated biomasses of isolated algae, as shown in Fig. 2. The functional groups of the raw and activated biomass are located at different wave numbers with higher transmittance values for raw biomass. The FT-IR spectra display the wave number of absorption peaks, indicating the nature of the raw and activated biomasses of Chlamydomonas variabilis. The bands at 3553 and $3409 \mathrm{~cm}^{-1}$ represent the bonded -OH of carboxylic groups on their surface. The band at $3240 \mathrm{~cm}^{-1}$ represents the stretching of the $-\mathrm{NH}$ group. The aliphatic $\mathrm{C}-\mathrm{H}$ group is represented by the bands at 2960-2 920 and $2850 \mathrm{~cm}^{-1}$. The bands within $2366-2028 \mathrm{~cm}^{-1}$ represent the stretching of the S-H group in the activated biomass. The peaks at $1637-1617 \mathrm{~cm}^{-1}$ represent the stretching of carbonyl group $\left(-\mathrm{HC}=\mathrm{O}, \mathrm{R}_{2} \mathrm{C}=\mathrm{O}\right)$; these groups can be conjugated or nonconjugated to aromatic rings (Cesar and Marco, 2004).

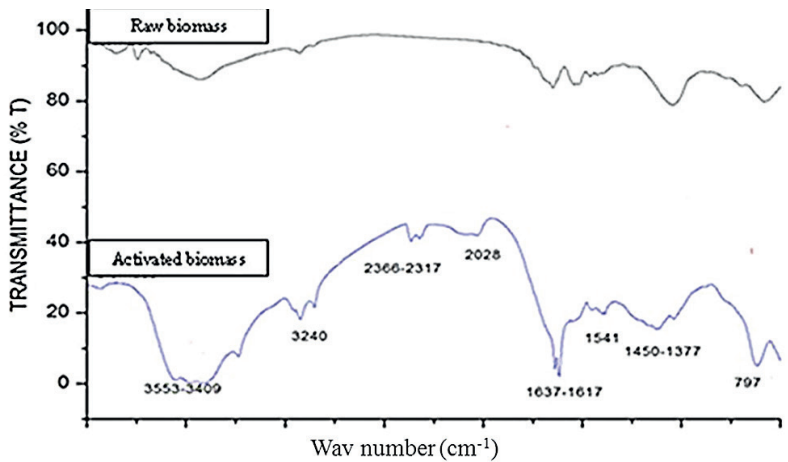

Figure 2

FT-IR spectra of raw and activated biomass of Chlamydomonas variabilis 
The bands at $1450-1377 \mathrm{~cm}^{-1}$ represent the stretching of amides $(\mathrm{C}-\mathrm{N}$ and $\mathrm{N}-\mathrm{H})$ from proteins. It has been well documented that these functional groups located on the cell wall react with dye species and facilitate dye-binding processes. (Kumar et al., 2015; Bakatula et al., 2014; Bulgariu and Bulgariu, 2014; Abbas et al., 2013a \& b; Chinedu et al., 2012; Monteiro et al., 2012; Zakhama et al., 2011).

\section{High resolution transmission electron microscopy (HRTEM)}

The HRTEM examination of the raw and activated biomasses of Chlamydomonas (Fig. 3) revealed the morphological nature of the biomass materials. The biomasses are characterized by an irregular surface with nanopores and nanoparticles that can facilitate dye sorption. Furthermore, Chlamydomonas is characterized by a sheath or projection that might be one of the defense mechanisms against dye toxicity. This sheath might prevent the dye from entering the algal cell via the functional chemical groups on its surface which complex or chelate the dyes (Bergey, 1989).

\section{Energy dispersive X-ray spectroscopy (EDX)}

The raw and activated biomasses of Chlamydomonas variabilis were characterized and examined by using EDX to determine their chemical composition as shown in Fig 4.

Carbon and oxygen were abundant components of the raw and activated biomasses of Chlamydomonas, with percentage weights of $55.2 \% \mathrm{C}$ and $34.1 \% \mathrm{O}$ for raw biomass and of $62.1 \%$ $\mathrm{C}$ and $31.2 \% \mathrm{O}$ for activating biomass. EDX is a useful tool for evaluating the elemental and chemical components of biosorbents. The abundant components revealed by EDX as the major groups in the two biomasses are compatible with FT-IR data, with many functional groups playing roles in biosorption (Dmytryk et al., 2014).

\section{Batch adsorption experiments}

\section{Determination of the optimum conditions for dye removal}

The optimum adsorption conditions ( $\mathrm{pH}$, contact time, algal dose, and initial metal concentration) for $\mathrm{MB}$ removal are shown in Fig. 5. pH is considered to be the most important parameter affecting dye biosorption from solutions (Hammud et al., 2011; Farzadkia et al., 2012). Here, the best adsorption was achieved at $\mathrm{pH} 7$, with percentage removal of $79.9 \%$ and $100 \%$ for raw and activated biomasses, respectively. Mokhtar et al. (2017) found that MB uptake by marine macro-alga Euchema spinosum was in an equilibrium state with slight fluctuations observed at $\mathrm{pH} 4$ and above, They explain this as being due to the biosorbent surface becoming positively charged when the $\mathrm{pH}$ is between 3.5 and 5.8, whereas the biosorbent surface began to be negatively charged at $\mathrm{pH}$ $>5.8$. Thus, at a higher $\mathrm{pH}$ of the solution, absorption of positively charged dye molecules, such as cationic dyes, is electrostatically favorable. Furthermore, in the present study, the percentage removals of $\mathrm{MB}$ by raw and activated biomass were achieved at $78.9 \%$ and $97.3 \%$, respectively, through 15 min of contact time. Sagar and Rastog (2017) observed that $\mathrm{MB}$ adsorption by the dried biomass of Oscillatoria spp. increased with time, until reaching a constant value at which no further dye was removed from the solution, with the maximum adsorption occurring within the first $60 \mathrm{~min}$.

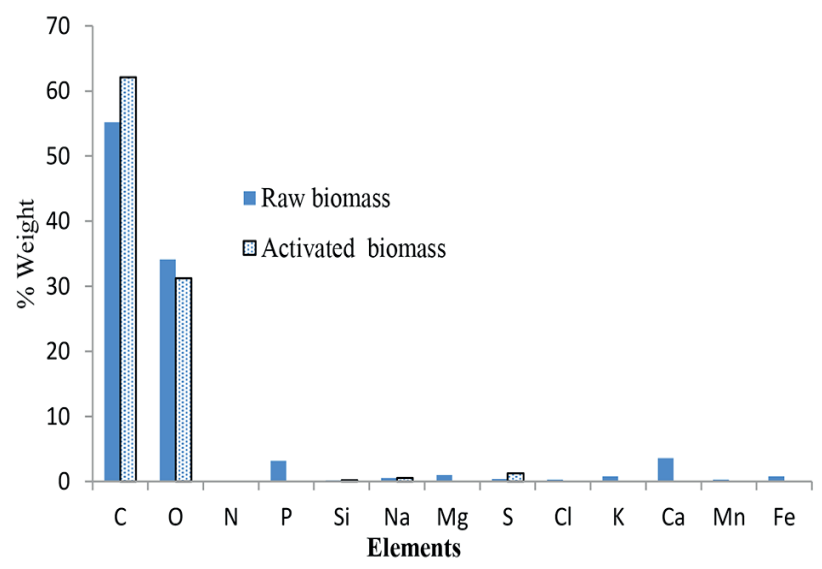

Figure 4

Energy dispersive $X$-ray microanalysis (EDX) for raw and activated biomass of Chlamydomonas

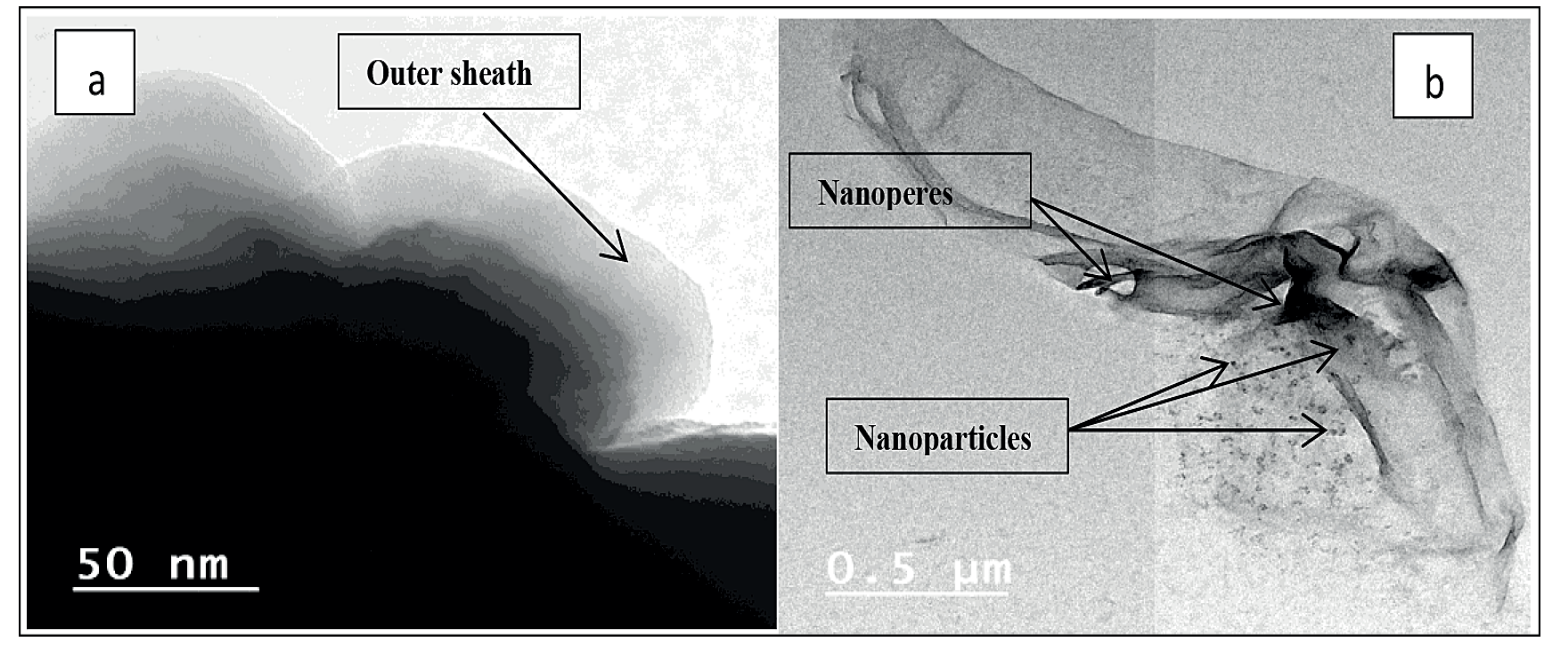

Figure 3

TEM micrographs of (a) raw and (b) activated biomasses of Chlamydomonas variabilis showing cell with the outer sheath, an irregular surface, and nanopores and nanoparticles 

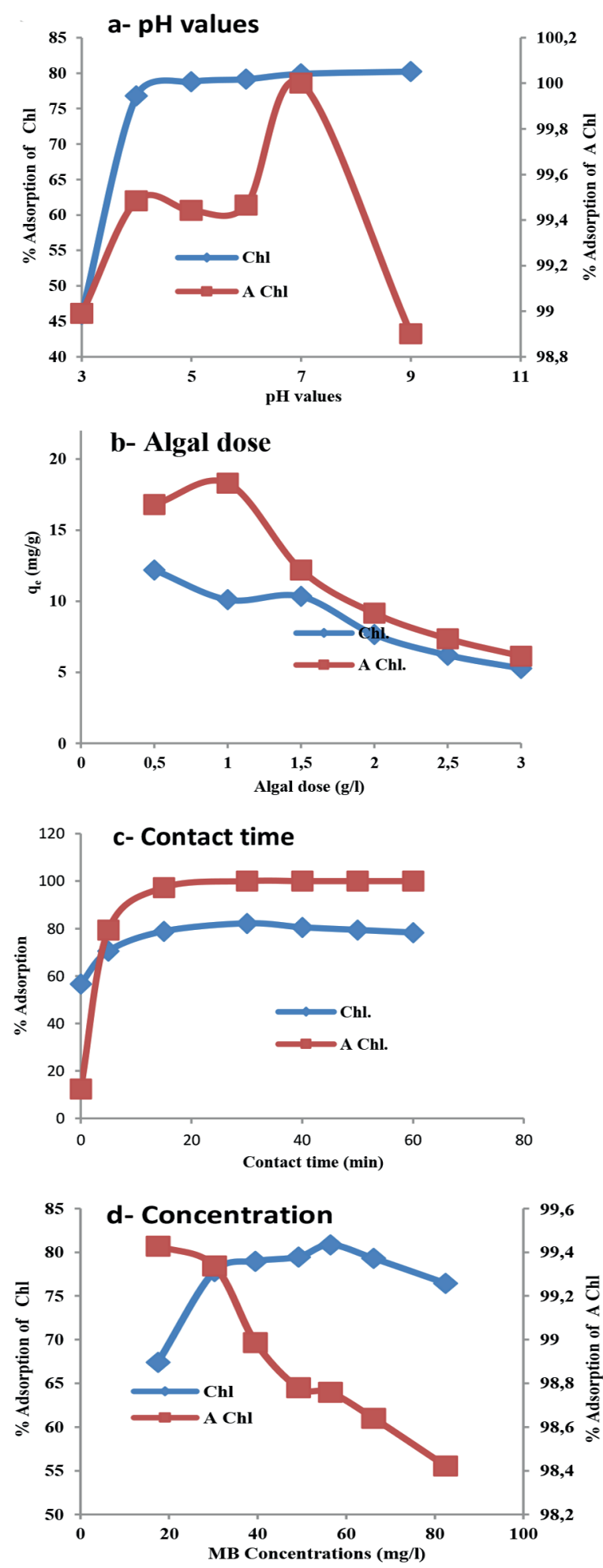

Figure 5

The optimum conditions for MB adsorption by dried (Chl) and activated (A Chl) biomass of Chlamydomonas

However, Moghazy and Abdo (2018) found that the contact time at which maximum MB removal of $89.5 \%$ was achieved was $30 \mathrm{~min}$, using the dried microalgal biomass collected from a high-rate algal pond.
The maximum removal of $\mathrm{MB}$ was achieved at a biosorbent doses of $1.5 \mathrm{~g} \cdot \mathrm{L}^{-1}$ for raw biomass and $1 \mathrm{~g} \cdot \mathrm{L}^{-1}$ for activated biomass; however, the adsorption capacity $\left(q_{\mathrm{e}}\right)$ was 10.3 and $18.3 \mathrm{mg} \cdot \mathrm{g}^{-1}$, respectively. Deokar and Sabale (2014) showed that $0.1 \mathrm{~g} \cdot \mathrm{L}^{-1}$ of dried Ulva lactuca was found to be the optimal adsorbent dose.

Regarding the optimum initial dye concentration, it was shown that the activated biomass removed more than $98 \%$ of $\mathrm{MB}$ at a concentration of $82.4 \mathrm{mg} \cdot \mathrm{L}^{-1}$, whereas the raw biomass achieved a maximum removal not exceeding $80.8 \%$ at an $\mathrm{MB}$ concentration of $56.4 \mathrm{mg} \cdot \mathrm{L}^{-1}$. Deokar and Sabale, (2014) found that the dried biomass of Ulva lactuca yielded a maximum removal of approximately $65 \%$ at an initial $\mathrm{MB}$ concentration $100 \mathrm{mg} \cdot \mathrm{L}^{-1}$.

\section{Determination of point of zero charge $\left(\mathrm{pH}_{p z c}\right)$}

At $\mathrm{pH}_{\mathrm{pzc}}$, the biosorbent has zero charge on its surface. As shown in Fig. 6, the two curves of dried and activated biosorbents cross the y-axis zero line at $\mathrm{pH} 6.8$ and 6.9, respectively. The surface of dried and activated biosorbents was positively charged at $\mathrm{pH}<6.8$ and 6.9. At $\mathrm{pH}>\mathrm{pH}_{\mathrm{PZC}}$ the surface of biosorbents began to be negatively charged. Thus, at a higher $\mathrm{pH}$ solution, biosorption of positively charged molecules, such as cationic dyes, is electrostatically favorable. At $\mathrm{pH}>\mathrm{pH}_{\mathrm{pzc}}$, the biosorption of cationic dye onto algal biosorbents is favourable due to the presence of active functional groups (Yagub et al., 2014).

\section{Application of biosorption isotherms}

Isotherm data acquired for MB removal by the raw and activated biomasses is presented in Table 2 and Figs 7 and

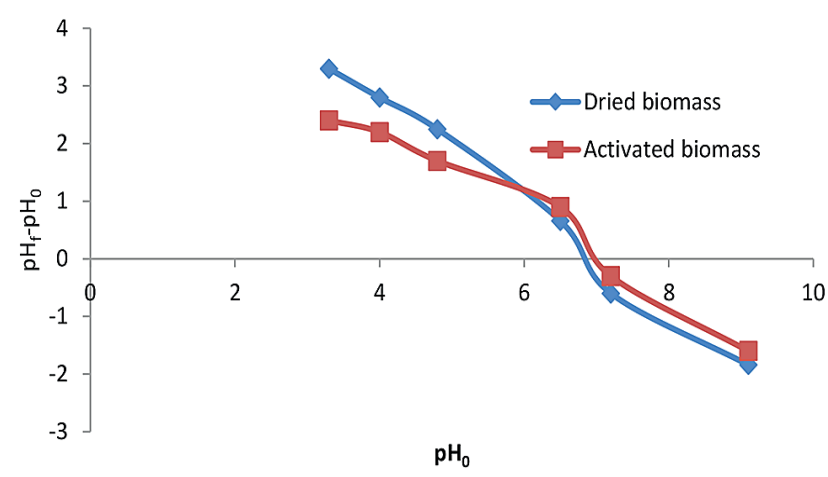

Figure 6

PZC plot of dried and activated biosorbent

TABLE 2

Isotherm models parameters for the raw and activated algal biomass

\begin{tabular}{|l|c|c|}
\hline Langmuir constants & Raw biomass & Activated biomass \\
\hline$q_{\max }(\mathrm{mg} / \mathrm{g})$ & 18.3 & 115 \\
\hline$R^{2}$ & 0.618 & 0.929 \\
\hline Freundlich constants & & \\
\hline$K_{\mathrm{f}}$ & 1.26 & 68.5 \\
\hline$N$ & 0.79 & 1.73 \\
\hline$R^{2}$ & 0.862 & 0.99 \\
\hline
\end{tabular}


8, represented by the linearized Langmuir and Freundlich isotherms. The Langmuir and Freundlich isotherms exhibited a better fit when using the activated biomass data than the raw biomass data, with $R^{2}$ values greater than 0.9 (Wattanachai et al., 2011), while the two isotherm data of the raw biomass did not fit well $\left(R^{2}>0.9\right)$. The Langmuir maximum sorption capacity $\left(q_{\max }\right)$ of the raw and activated biomass was found to be 18.3 and $115 \mathrm{mg} \cdot \mathrm{g}^{-1}$, respectively. The $q_{\max }$ of the Langmuir model was assumed to represent the maximum amount of $\mathrm{MB}$ which forms a complete monolayer on the surface of the biosorbent. The Freundlich constant ( $n$ ) was 1.26 and 67.1 for the raw and activated biomass, respectively. In studying raw and modified Carolina algae, a linear relationship for the Langmuir isotherm was found by Hammud et al. (2011), with an $R^{2}$ value of $>0.9$ and $q_{\max }$ equal to 55 and $64 \mathrm{mg}^{-g^{-1}}$ for raw and formaldehyde-modified algae, respectively. However, they found that the Freundlich isotherm showed a reduced fit $\left(R^{2}\right.$ less than 0.9 ) for both biosorbents, with a constant $(n)$ equal to 2.5 and 2.7 for the raw and formaldehyde-modified algae, respectively. Mikati et al. (2013) observed that the $q_{\max }$ of acid (HCl) modified Chaetophora elegans was greater than that of the raw biomass; however $q_{\max }$ was 143 and $320 \mathrm{mg} \cdot \mathrm{g}^{-1}$ for the raw and modified biomass, respectively.

The raw biosorbent shows a lower sorption capacity than that of chemically modified biomaterials. The chemical modification increases the active sites' number or replaces the existing sites by more attractive ones. Many inorganic or organic chemical reagents are used for this purpose, so Table

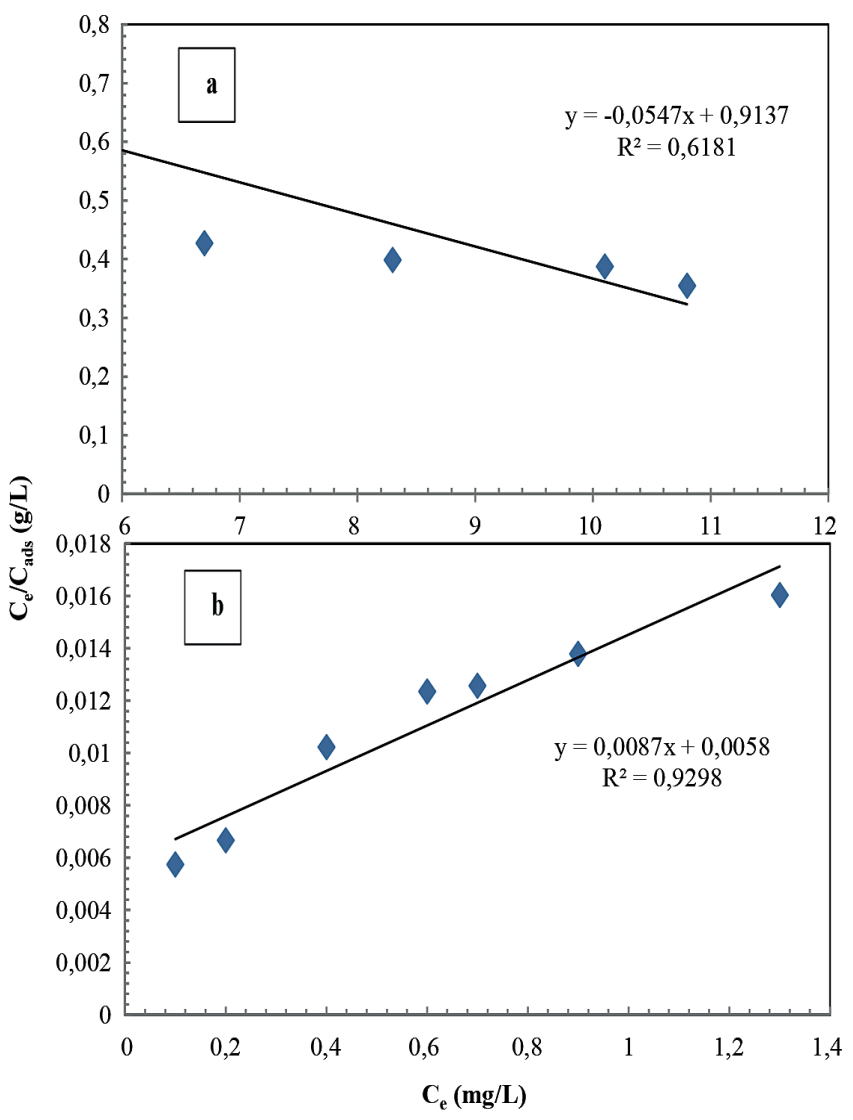

Figure 7

Langmuir isotherm for $M B$ adsorption onto (a) raw and (b) activated algal biomasses
3 show the comparison of the uptake of pollutants by different modified and unmodified biomaterials (Mikati et al., 2013).

\section{Application of kinetic modelling}

In order to investigate the adsorption of $\mathrm{MB}$ onto dried and activated Chlamydomonas variabilis biomass, two kinetic models were used, including the pseudo-first-order model and pseudo-second-order model. The values of the first-order rate constant, $k_{\mathrm{f}}$, are determined from Eq. 3 as shown in Table 4 and Figs 9 and 10 . The $R^{2}$ values obtained were less than 0.9 and the calculated $q_{\mathrm{e}}$ values did not agree with the experimental values which reveal that the adsorption does not follow the pseudofirst-order equation.

By applying the pseudo-second-order kinetic model, the $R^{2}$ value was greater than 0.99 , and the calculated $q_{\mathrm{e}}$ value is very close to the experimental value, which suggests that $\mathrm{MB}$ adsorption could occur by chemisorption. Therefore, it could be suggested that the adsorption of $\mathrm{MB}$ follows the pseudosecond-order model better than the pseudo-first-order one.

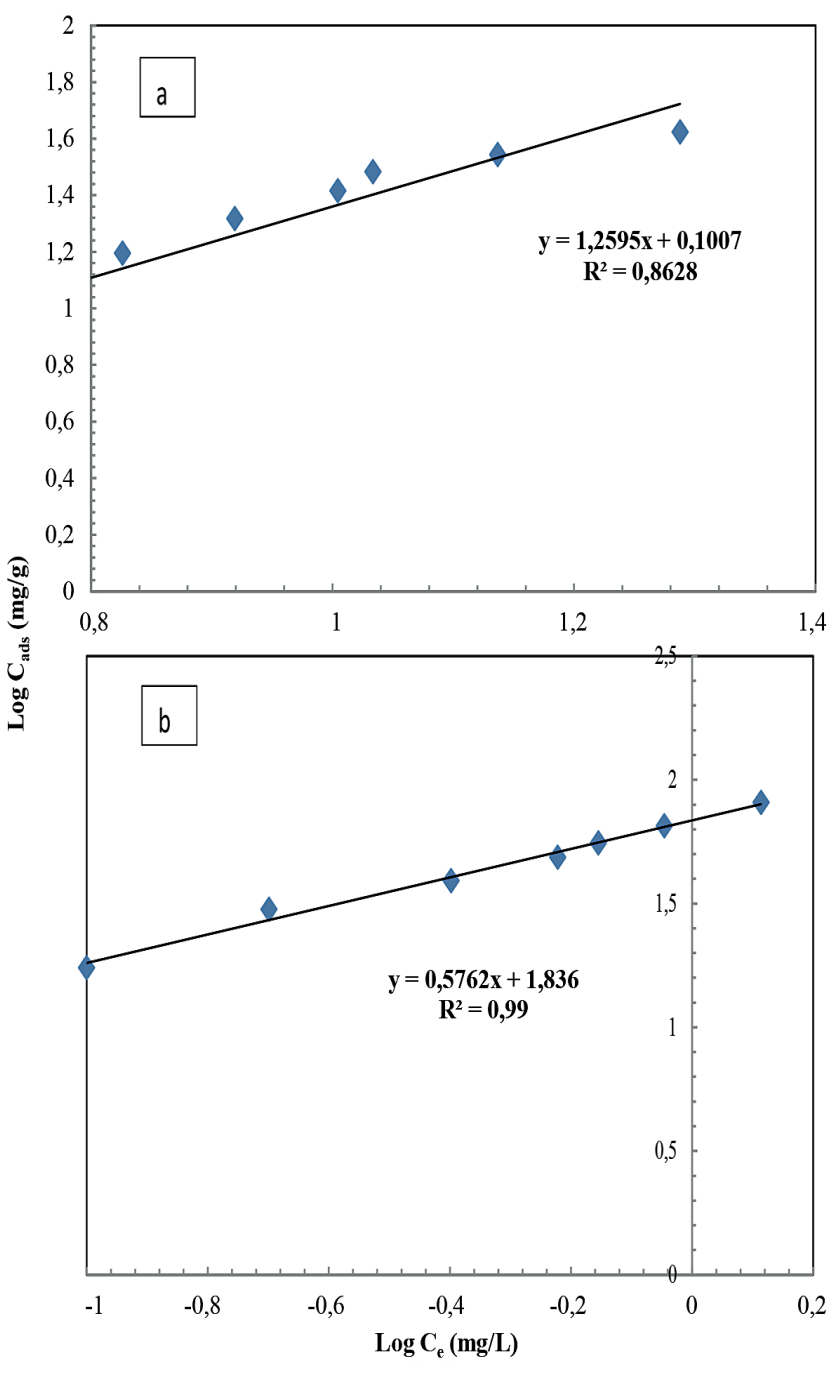

Figure 8

Freundlich isotherm for MB adsorption onto (a) raw and (b) activated algal biomasses 
TABLE 3

Comparison of the uptake of pollutants by modified and unmodified biomaterials

\begin{tabular}{|c|c|c|c|c|c|}
\hline \multirow{2}{*}{ Biomass } & \multirow{2}{*}{ Pollutant } & \multirow{2}{*}{ Treatment } & \multicolumn{2}{|c|}{$q_{\max }(\mathrm{mg} / \mathrm{g})$} & \multirow{2}{*}{ Sources } \\
\hline & & & Raw & Modified & \\
\hline Carolina & \multirow{4}{*}{ MB } & $\mathrm{H}_{2} \mathrm{CO}$ & 55 & 64 & Hammud et al. (2011) \\
\hline \multirow{2}{*}{ Chaetophora elegans } & & $\mathrm{HCl}$ & 143 & 320 & \multirow{2}{*}{ Mikati et al. (2013) } \\
\hline & & Citric acid & 143 & 20 & \\
\hline Chlamydomonas variabilis & & $\mathrm{H}_{2} \mathrm{SO}_{4}$ & 18.3 & 115 & This work \\
\hline Rice Straw & MG & \multirow{3}{*}{ Citric acid } & - & 256.4 & Gong et al. (2006) \\
\hline \multirow{2}{*}{ Pinus merkusii } & $\mathrm{Pb}(\mathrm{II})$ & & 7.71 & 82.64 & \multirow{2}{*}{ Low et al. (2004) } \\
\hline & $\mathrm{Cu}(\mathrm{II})$ & & 2.56 & 23.70 & \\
\hline \multirow{2}{*}{ Cladophora glomerate } & $\mathrm{Pb}(\mathrm{II})$ & \multirow{2}{*}{$\mathrm{HCl}$} & 26.5 & 36.6 & \multirow{2}{*}{ Yalçın et al. (2008) } \\
\hline & $\mathrm{Cu}(\mathrm{II})$ & & 15.5 & 22.5 & \\
\hline
\end{tabular}

\begin{tabular}{|c|c|c|c|c|c|c|c|}
\hline \multicolumn{8}{|c|}{$\begin{array}{c}\text { TABLE } 4 \\
\text { Kinetic values calculated for MB sorption onto dried and activated biomass }\end{array}$} \\
\hline \multirow{2}{*}{ Adsorbent } & \multicolumn{3}{|c|}{ Pseudo first order } & \multicolumn{4}{|c|}{ Pseudo second order } \\
\hline & $K_{1}$ & $R_{2}$ & $q_{\mathrm{e}}\left(\mathrm{mg} \cdot \mathrm{g}^{-1}\right)$ & $K_{2}$ & $R_{2}$ & $q_{\mathrm{e}^{\prime}} \mathrm{cal}\left(\mathrm{mg} \cdot \mathrm{g}^{-1}\right)$ & $q_{\mathrm{e}^{\prime}} \exp \left(m g^{\cdot g-1}\right)$ \\
\hline Dried biomass & 0.043 & 0.722 & 3.8 & 0.23 & 0.9994 & 22.0 & 22.4 \\
\hline Activated biomass & 0.042 & 0.438 & 4.7 & 0.08 & 0.9995 & 18.2 & 18.0 \\
\hline
\end{tabular}
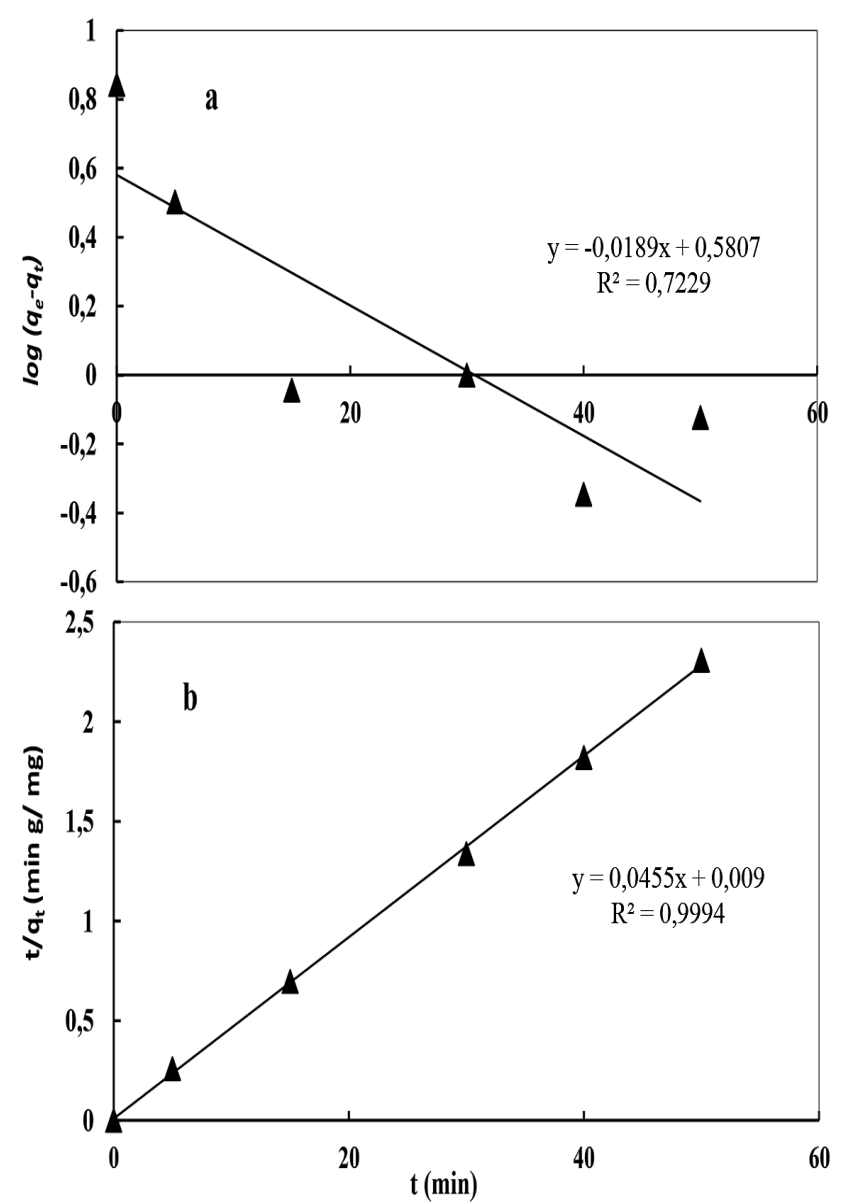

Figure 9

Plot of $a$ - pseudo first order and $b$ - $p$ seudo second order equation for $M B$ adsorption onto the dried biomass
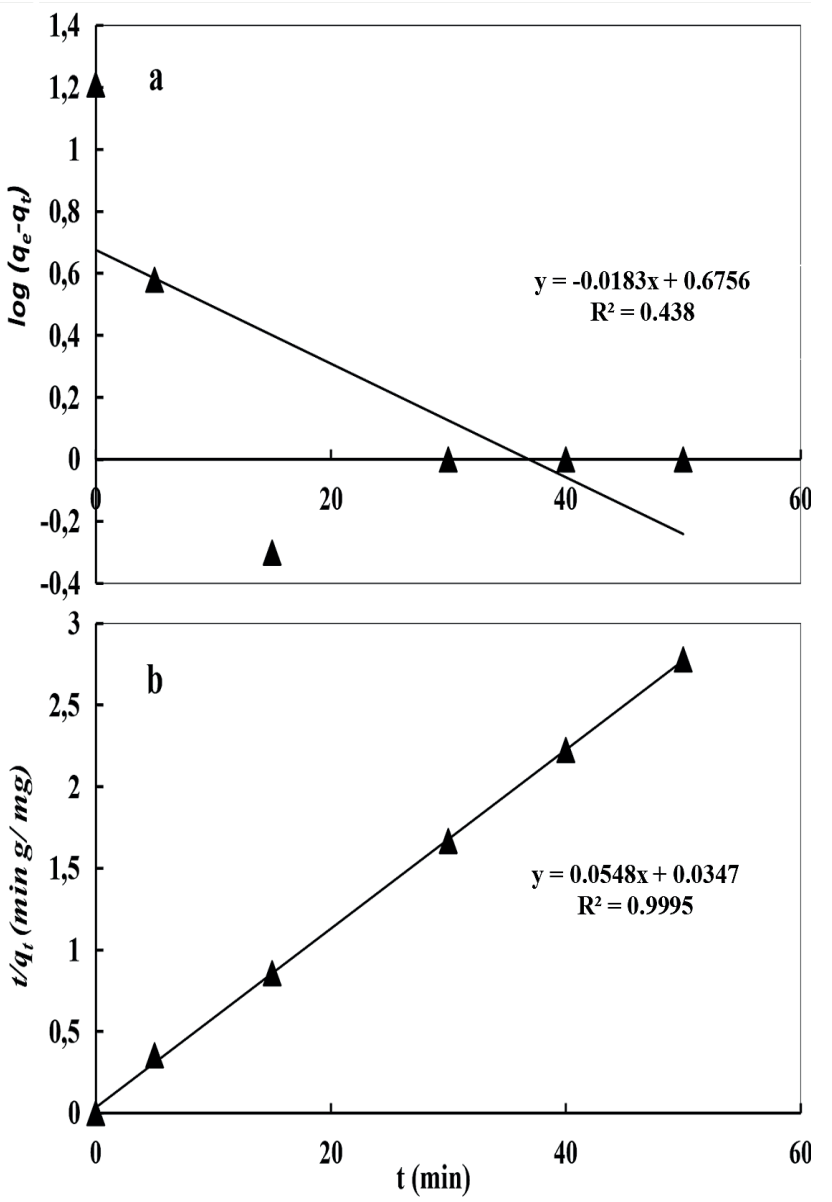

Figure 10

Plot of a-pseudo first order and $b$-pseudo second order equation for $M B$ adsorption onto the activated biomass 
Kostić et al. (2018) found that the kinetic results of the sorption process of dye by mesoporous triple-metal nanosorbent were well fitted to the pseudo-second-order model.

Özkan (2010) and Wang and Chen (2009) stated that adsorption kinetics data for algal biomasses are well represented by the pseudo-second-order model, thus supporting the basic assumption in the model that chemisorption or effective electrostatic interactions play a major role in adsorption. However, Kostić et al. (2017) concluded that the pseudo-secondorder model can better describe the kinetics of sorption of MB onto xanthated corn cob. The sorption capacities calculated by the pseudo-first and pseudo-second model are close to those determined by experiments.

\section{CONCLUSION}

The data acquired from the biomass characterization show that the raw and activated biomasses of the green alga Chlamydomonas variabilis are effective biosorbents for MB. The biosorbent optimization analyses revealed that the optimum adsorption of $\mathrm{MB}$ occurred through $30 \mathrm{~min}$ of contact time at $\mathrm{pH} 7$ and an biosorbent dose of 1.5 and $1.0 \mathrm{~g} \cdot \mathrm{L}^{-1}$ of raw and its activated biosorbent, respectively. $\mathrm{pH}_{\mathrm{pzc}}$ data explain that the surface of biosorbents began to be negatively charged at $\mathrm{pH}>6.8$ and 6.9 for dried and activated biomass, respectively, and this is favourable for biosorption of cationic dye onto algal biosorbents on the active sites of many functional groups. Furthermore, the Langmuir and Freundlich isotherms of activated biomass showed a better fit $\left(R^{2}>0.9\right)$ than did those of raw biomass, with a $q_{\max }$ of 18.3 and $115 \mathrm{mg} \cdot \mathrm{g}^{-1}$ for raw and activated biomass, respectively. A minimum removal of greater than $98 \%$ at an $\mathrm{MB}$ concentration of $82.4 \mathrm{mg} \cdot \mathrm{L}^{-1}$ was achieved using $1 \mathrm{~g} \cdot \mathrm{L}^{-1}$ activated biomass, whereas the maximum removal at an $\mathrm{MB}$ concentration of $56.4 \mathrm{mg} \cdot \mathrm{L}^{-1}$ did not exceed $80.8 \%$ using $1.5 \mathrm{~g} \cdot \mathrm{L}^{-1}$ raw biomass. The kinetic data proved that the adsorption of MB follows the pseudo-second-order model better than the pseudo-first-order one so that it is suggested that the biosorpton mechanism is chemisorption reaction. These findings indicate that the acid-activated algal biomass of Chlamydomonas variabilis can be considered a promising biosorbent for the effective removal of dye.

\section{ACKNOWLEDGEMENTS}

The author would like to thank the Hydrobiology Lab, Water Pollution Department, NRC, for providing a supporting technical environment and tools. This research did not receive any specific grant from funding agencies in the public, commercial, or not-for-profit sectors.

\section{REFERENCES}

ABBAS HS, MOHAMMED AA and AL-MUSAWI TJ (2013a) Competitive biosorption of lead, cadmium, copper, and arsenic ions using algae. Environ. Sci. Pollut. Res. 20 3011-3023. https://doi. org/10.1007/s11356-012-1208-2.

ABBAS HS, MOHAMMED AA and AL-MUSAWI TJ (2013b) column biosorption of lead, cadmium, copper, and arsenic ions onto algae. J. Bioprocess. Biotech. 3 1. https://doi. org/10.4172/2155-9821.1000128.

AL-FAWWAZ AT and ABDULLAH M (2016) decolorization of methylene blue and malachite green by immobilized Desmodesmus sp. isolated from north Jordan. Int. J. Environ. Sci. Dev. 7 (2) 95-99. https://doi.org/10.7763/IJESD.2016.V7.748.
BADR SA, ASHMAWY AA, EL-SHERIF IY and MOGHAZY RM (2016) Non-conventional low-cost biosorbents for adsorption and desorption of heavy metals. Res. J. Pharm. Biol. Chem. Sci. 7 (4) 3110-3122.

BAKATULA EN, CUKROWSKA EM, WEIERSBYE IM, MIHALYCOZMUTA L, PETER A and Tutu H (2014) Biosorption of trace elements from aqueous systems in gold mining sites by the filamentous green algae (Oedogonium sp.) Geochem. Explor. 144 492-503. https://doi.org/10.1016/j.gexplo.2014.02.017.

BANAT IM, NIGAM P, SINGH D and MARCHANT R (1996) Microbial decolorization of textile-dye containing effluents: A Review. Bioresour. Technol. 58 217-227. https://doi.org/10.1016/ S0960-8524(96)00113-7.

BERGEY DH (1989) Bergey's Manual of Systematic Bacteriology. Williams \& Wilkins Co., Baltimore, MD. 1718-1720. https://doi. org/10.1007/0-387-29298-5.

BHARATHI KS and RAMESH ST (2013) Removal of dyes using agricultural waste as low cost adsorbents: a review. Appl. Water Sci. 3 773-790. https://doi.org/10.1007/s13201-013-0117-y.

BROUERS F and AL-MUSAWI TJ (2015) On the optimal use of isotherm models for the characterization of biosorption of lead onto algae. J. Molec. Liq. 212 46-51. https://doi.org/10.1016/j. molliq.2015.08.054.

BULGARIU L and BULGARIU D (2014) Enhancing biosorption characteristics of marine green algae (Ulva lactuca) for heavy metals removal by alkaline treatment. J. Bioprocess Biotech. 41. https://doi.org/10.4172/2155-9821.1000146.

CESAR TTR and MARCO ZAA (2004) Biosorption of heavy metals using rice milling by-products: characterization and application for removal of metals from aqueous effluents. Chemosphere $\mathbf{5 4}$ 987-995. https://doi.org/10.1016/j.chemosphere.2003.09.001.

CHINEDU JO, CHARLES M and ONYEMA MA (2012) Equilibrium, kinetic, thermodynamic and thermal stability studies on sorption of $\mathrm{Ni}$ (II) ions from aqueous solution using dead biomass of fresh water green alga Cosmarium panamense. Der Chem. Sin. 3 (1) 38-51.

CLARK EA and ANLIKER R (1980) Organic Dyes and Pigments. Handbook of Environmental Chemistry. Springer Verlag, Berlin. 181-125. https://doi.org/10.1007/978-3-540-38522-6-7.

DEOKAR R and SABALE A (2014) Biosorption of methylene blue and malachite green from binary solution onto Ulva Lactuca. Int. J. Curr. Microbiol. Appl. Sci. 3 (5) 295-304.

DMYTRYK A, SAEID A and CHOJNACKA K (2014) Biosorption of microelements by spirulina: Towards technology of mineral feed supplements. Sci. World J. 2014 doi: 10.1155/2014/356328. https:// doi.org/10.1155/2014/356328.

El-SIKAILY A, EL NEMR A, KHALED A and ABDELWEHAB O (2007) Removal of toxic chromium from wastewater using green alga Ulva Lactuca and its activated carbon. J. Hazardous Mater. 148 (1-2) 216-228. https://doi.org/10.1016/j.jhazmat.2007.01.146.

FARZADKIA M, GHOLAMI M, KERMANI M and YAGHMAEIAN K (2012) Biosorption of hexavalent chromium from aqueous solutions by chemically modified brown algae of Sargassum sp. and dried activated sludge. Asian J. Chem. 24 (11) 5257-5263.

FIGUEIRA M, VOLESKY B, AZARIAN K and CIMINELLI VS (1999) Multimetal biosorption in a column using Sargassum biomass. In: Amils R and Ballester A (eds) Biohydrometallurgy and the Environment toward the Mining of the 21st century (Part B): International Biohydrometallurgy Symposium - Proceedings. Elsevier Science, Amsterdam. 503-512. https://doi.org/10.1016/ S1572-4409(99)80139-4.

FREUNDLICH H (1907) Ueber die adsorption in loesungen. Z. Phys. Chem. 57 385-470.

FRIEDRICH H (1976) Bacillariophyta (Diatomaceae). Otto Koeltz Science Publishers, W-Germany.

FU Y and VIRARAGHAVAN T (2002) Dye biosorption sites in Aspergillus niger. Bioresour. Technol. 82 139-145. https://doi. org/10.1016/S0960-8524(01)00172-9.

GEITLER L (1932) Cyanophyceae. In: Rabenhorst L (ed.) KryptogamenFlora von Deutschland, Österreich $u$ nd der Schweiz Vol. $14\left(2^{\text {nd }}\right.$ edn). 673-1196, i-vi.

GHOSH D and BHATTACHARYYA KG (2002) Adsorption of methylene blue on kaolinite. Appl. Clay Sci. 20 295-300. https://doi. org/10.1016/S0169-1317(01)00081-3 
GONG R, JIN Y, CHEN F, CHEN J and LIU Z (2006) Enhanced malachite green removal from aqueous solution by citric acid modified rice straw. J. Hazardous Mater. 137 (2) 865-870. https:// doi.org/10.1016/j.jhazmat.2006.03.010.

GUIBAUD G, TIXIER N, BOUJU A and BAUDU M (2003) Relation between extracellular polymers composition and its ability to complex $\mathrm{Cd}, \mathrm{Cu}$ and $\mathrm{Pb}$. Chemosphere 52 1701-1710. https://doi. org/10.1016/S0045-6535(03)00355-2.

HAMDAOUI O and CHIHA M (2007) Removal of methylene blue from aqueous solutions by wheat bran. Acta Chim. Slov. $\mathbf{5 4} 407$. https://doi.org/10.1016/j.jhazmat.2006.10.053.

HAMMUD HH, FAYOUMI L, HOLAIL H and MOSTAFA ME (2011) biosorption studies of methylene blue by mediterranean algae carolina and its chemically modified forms. linear and nonlinear models' prediction based on statistical error calculation. Int. J. Chem. 3 (4) 147-163. https://doi.org/10.5539/ijc.v3n4p147.

HO YS, NG JCY, and MCKAY G (2000) Kinetics of pollutant sorption by biosorbents: Review. Sep. Purif. Meth. 29 (2) 189-232. https:// doi.org/10.1081/SPM-100100009.

KALME SD, JADHAV SU, PARSHETTI GK and GOVINDWAR SP (2010) Biodegradation of Green HE4B: Co-substrate effect, biotransformation enzymes and metabolite toxicity analysis. Ind. J. Microbiol. 50 156-164. https://doi.org/10.1007/s12088-010-0001-5.

KOMÁREK J and FOTT B (1983) Chlorophyceae (Grünalgen), Ordnung Chlorococcales. In: Huber-Pestalozzi G (ed.) Das Phytoplankton des Susswasers; Systematik und Biologie. E. Schweizerbart'sche Verlagsbuchhhandlung, Stuttgart. Bd 7, fasc. 1, 1044 p. [15].

KOSTIĆ M, ĐORĐEVIĆ M, MITROVIĆ J, VELINOV N, BOJIĆ D, ANTONIJEVIĆ M and BOJIĆ A (2017) Removal of cationic pollutants from water by xanthated corn cob: optimization, kinetics, thermodynamics, and prediction of purification process. Environ. Sci. Pollut. Res. 24 (21) 17790-17804. https://doi. org/10.1007/s11356-017-9419-1.

KOSTIĆ M, RADOVIĆ M, VELINOV N, NAJDANOVIĆ S, BOJIĆ D, HURT A and BOJIĆ A (2018) Synthesis of mesoporous triple-metal nanosorbent from layered double hydroxide as an efficient new sorbent for removal of dye from water and wastewater. Ecotoxicol. Environ. Saf. 159 (February) 332-341. https://doi.org/10.1016/j. ecoenv.2018.05.015

KUMAR KS, DAHMS HU, WON EJ, LEE JS and SHIN KH (2015) Microalgae - a promising tool for heavy metal remediation. Ecotoxicol. Environ. Saf. 113 329-352. https://doi.org/10.1016/j. ecoenv.2014.12.019.

LANGMUIR I (1918) The adsorption of gases on plane surface of glass, mica and platinum. J. Am. Chem. Soc. 40 1361-1403. https://doi. org/10.1021/ja02242a004.

LIANG J, XIA J and LONG J (2017) Biosorption of methylene blue by nonliving biomass of the brown macroalga Sargassum hemiphyllum. Water Sci Technol.. 76 (6) 1574-1583. https://doi. org/10.2166/wst.2017.343.

LOW KS, LEE CK and MAK SM (2004) Sorption of copper and lead by citric acid modified wood. Wood Sci. Technol. 38 (8) 629-640. https://doi.org/10.1007/s00226-003-0201-9

MIKATI F, SAADE NA, SLIM KA and EL JAMAL M (2013) Biosorption of methylene blue on chemically modified Chaetophora Elegans algae by carboxylic acids. J. Sci. Ind. Res. (India). 72 (7) 428-434.

MOGHAZY RM AND ABDO SM (2018) The efficacy of microalgal biomass collected from high rate algal pond for dyes biosorption and biofuel production. Res. J. Chem. Environ. 22 (11) 54-60.

MOKHTAR N, AZIZ EA, ARIS A, ISHAK WFW, SAADIAH N and ALI M (2017) Biosorption of azo-dye using marine macro-alga of Euchema Spinosum. Biochem. Pharmacol. 5 (6) 5721-5731. https:// doi.org/10.1016/j.jece.2017.10.043.

MONTEIRO CM, CASTRO PML and MALCATA FX (2012) Metal uptake by microalga: underlying mechanisms and practical applications. Biotechnol. Prog. 28 (2) 299-311. https://doi. org/10.1002/btpr.1504.

MONTEIRO MS, DE FARIAS RF, CHAVES JAP, SANTANA SA, SILVA HAS and BEZERRA CWB (2017) Wood (Bagassa guianensis $A u b l$ ) and green coconut mesocarp (cocos nucifera) residues as textile dye removers (Remazol Red and Remazol Brilliant Violet). J. Environ. Manage. 204 23-30. https://doi.org/10.1016/j. jenvman.2017.08.033.

ÖZKAN E (2010) Thermodynamics and kinetic studies of biosorption of a basic dye from aqueous solution using green algae Ulothrix sp. Colloid. Surf. B: Biointerf. 76 279-285. https://doi.org/10.1016/j. colsurfb.2009.11.004.

PINTO TF, BEZERRA CWB, SILVA DS, SILVA FILHO EC, VIEIRA AP, AIROLDI C, MELO JC, SILVA HA and SANTANA SAA (2016) Sawdust derivative for environmental application: chemistry, functionalization and removal of textile dye from aqueous solution. An. Acad. Bras. Cienc. 88 1212-1220. https://doi. org/10.1590/0001-3765201620140656.

SAGAR S and RASTOGI A (2017) Biosorption of methylene blue from aqueous solutions by using blue, green algae Oscillatoria sp.: Kinetic and equilibrium studies. J. Applicable Chem. 6 (3) 374-384.

SARWA P and VERMA SK (2013) Decolourization of Orange G dye by microalgae Acutodesmus obliques Strain PSV2 isolated from textile industrial site. Int. J. Appl. Sci. Biotechnol. 1 (4) 247-252. https:// doi.org/10.3126/ijasbt.vli4.9141.

SENTHILKUMAAR S, VARADARAJAN PR, PORKODI K and SUBBHURAAM CV (2005) Adsorption of methylene blue onto jute fiber carbon: kinetics and equilibrium studies. J. Colloid Interf. Sci. 284 78-82. https://doi.org/10.1016/j.jcis.2004.09.027.

STANIER RY, KUNISAWA MM and COHN-BAZIRE G (1971) Purification and properties of unicellular blue green algae (order Chroococcales). Bacteriol. Rev. 35 (2) 171-205. https://doi. org/10.1016/j.jbiotec.2013.07.020

WANG L, ZHANG C, WU F and DENG N (2007) Photodegradation of aniline in aqueous suspensions of microalgae. J. Photochem. Photobiol. B Biol. 87 49-57. https://doi.org/10.1016/j. jphotobiol.2006.12.006.

WANG XS and CHEN JP (2009) Removal of the azo dye congo red from aqueous solutions by the marine alga Porphyra yezoensis Ueda. Clean Soil Air Water 37 (10) 793-798. https://doi.org/10.1002/ clen.200900177.

WATTANACHAI Y, PAIRAT K and PRADUB R (2011) Biosorption of lead and cadmium ions by non-living aquatic macrophyte, Utricularia aurea. Sustain. Environ. Res. 21 (6) 369-374.

WEBER WJ AND MORRIS JC (1963). Kinetics of adsorption on carbon from solution. J. Sanit. Eng. Div. 89 (2) 31-60. https://doi. org/10.1080/002689796173345.

WILLIAMS DB and CARTER CB (1996) Transmission Electron Microscopy: A Textbook for Materials Science. Materials Science (Vol. 1-4). Springer,US. https://doi. org/10.1007/978-1-61779-415-5_23.

YAGUB MT, SEN TK, AFROZE S and ANG HM (2014) Dye and its removal from aqueous solution by adsorption: A review. $A d v$. Colloid Interf. Sci.. https://doi.org/10.1016/j.cis.2014.04.002.

YALÇIN E, ÇAVUŞOĞLU K, MARAŞ M and BIYIKOĞLU M (2008) Biosorption of lead (II) and copper (II) metal ions on Cladophora glomerata (L.) Kütz. (Chlorophyta) algae: Effect of algal surface modification. Acta Chim. Sloven. 55 (1) 228-232.

ZAKHAMA S, DHAOUADI H, and M'HENNI F (2011) Nonlinear mobilization of heavy metal removal from aqueous solution using Ulva lactuca algae. Bioresour. Technol. 102 (2) 786-796. https://doi. org/10.1016/j.biortech.2010.08.107.

ZAZOULI MA and MORADI E (2015) Adsorption Acid Red18 dye Using Sargassum Glaucescens Biomass from aqueous solutions. Iran. J. Health Sci. 3 (2) 7-13. 